Article

\title{
Land Acquisition in India: A Pareto and Kaldor-Hicks Perspective
}

\author{
Sankalp Sharma ${ }^{1, *}$, Anil Giri ${ }^{2}$, Tajamul Haque ${ }^{3}$ and Iuliia Tetteh ${ }^{4}$ \\ 1156 Science \& Technology Building, Kent State University-Tuscarawas, 330 University Drive NE, \\ New Philadelphia, $\mathrm{OH} 44663$, USA \\ 2 University of Central Missouri, Warrensburg, MO 64093, USA; giri@ucmo.edu \\ 3 The National Institution for Transforming India (NITI Aayog), New Delhi 110001, India; \\ drt.haque@gmail.com \\ 4 Department of Agriculture, llinois State University, Normal, IL 61761, USA; iproto1@ilstu.edu \\ * Correspondence: ssharm31@kent.edu; Tel.: +1-330-308-7488
}

Received: 24 April 2018; Accepted: 13 May 2018; Published: 18 May 2018

\begin{abstract}
Land acquisition by the government or a private entity to aid industrialization remains a critical policy concern. In 2013, The Right to Fair Compensation and Transparency in Land Acquisition, Rehabilitation and Resettlement Act (LARR Act of 2013) became the premier land law in India. The Act creates a transparent process through which buyers can acquire land for industrialization and other commercial activities. However, the succeeding government was dissatisfied with some provisions in the original Act and floated two Amendment Bills in 2014 and 2015. In this article, we examine if the proposed removal of the "Consent" clause, a key provision in the original Act, is necessary. The removal would allow the government to impose eminent domain under certain conditions. We propose that removing the "Consent" clause is necessary for social welfare maximization and maintain that compensation based on marginal utility of income is the correct approach as it maximizes social welfare and helps maintain a balanced budget.
\end{abstract}

Keywords: land use; land policy; land acquisition; welfare economics; pareto efficiency; Kaldor-Hicks efficiency

\section{Introduction}

Land acquisition for generating public goods such as infrastructure projects has remained an important policy concern in India. After a major land reform bill was passed in 2013, potential land buyers raised concerns about the draconian consent and compensation measures mandated in the bill. Land is a fixed resource and redistributing it among different groups through the market might result in second-best allocations. This implies that one group, the buyer or the seller, might be worse-off after the transaction occurs. However, the post-transaction redistribution of land may also result in higher overall social welfare [1]. Therefore, the role of the government in land markets must be reexamined. Due to complaints from members of the business community, the succeeding Indian government promulgated an amendment bill in 2015, which collapsed in the upper-house of the Indian parliament. This article examines the necessity of a key amendment proposed in the bill-the removal of the "consent clause" in five areas: industrial corridors, public-private partnership projects, rural infrastructure, affordable housing, and defense. In other words, the government wanted to retain the ability to impose eminent domain in the aforementioned areas. We ask whether the removal of the consent clause would have led to efficient land allocation outcomes.

During the early part of the 19th century, the British-India government passed legislations to acquire land for public use in the eastern and southern parts of the country against the demands of the 
land owners. Soon after this, the scope of these legislations was broadened to the rural and forest areas and they were collectively called The Land Acquisition Act of 1894. This was the first comprehensive land acquisition law in India. According to the law, land would be acquired for the creation of public goods, where the state would be the agent of acquisition from individual owners. The government would determine the price of the land parcel under consideration. As expected, the interpretation of a "public good" was broad and it compromised the rights of the land owners.

The Right to Fair Compensation and Transparency in Land Acquisition, Rehabilitation and Resettlement Act (LARR) was passed by the Indian Parliament in September 2013 [2]. The Act replaces the Land Acquisition Act of 1894 and is considered one of the signature achievements of the United Progressive Alliance, which was the ruling coalition party at the time. The Act creates a transparent process through which buyers can acquire land for industrialization and other commercial activities. However, the bill also requires owners to be adequately compensated and resettled. "Adequate compensation" implies that if a buyer acquires land at market value for any public purpose, then the land owner must be resettled with the option of a monthly allowance of up to $\$ 500$ for 20 years. ${ }^{1}$ The owner can also choose to receive a payment of $\$ 11,000$ upfront instead of the monthly allowance. ${ }^{2}$ If undeveloped land is resold, then the government shares $20 \%$ of the appreciated land value with the original owner. The Land Acquisition Bill of 1894 mandates that the market value of land must be determined by the three-year moving average of the land's price. The new Act maintains a variation of this provision and adds two other provisions to determine the market value of land: (1) "the value will be set as or the higher of the minimum value specified in the Indian Stamp Act, 1899 for the registration of sale deeds in the area, where the land is situated"; (2) "the value will be set as or the higher of the consented amount in case the land is acquired for private companies or public-private partnership projects".

The succeeding government, led by Prime Minister Narendra Modi, was dissatisfied with some clauses in the original Act and promulgated three amendment bills, one in 2014 and two in 2015, to address the concerns of potential land buyers. Nine amendments were introduced in the 2015 bill. One of these amendments was the exclusion of the "Consent" clause, which became contentious. In this paper, we examine the impact of the "Consent" clause in the original bill and ask if its removal is beneficial for social welfare. The removal of the "Consent" clause would allow the government to acquire land for industrial corridors, public private partnership (PPP) projects, rural infrastructure, affordable housing, and defense without the approval of the land owners. ${ }^{3}$ The original Act requires the consent of at least $80 \%$ land owners for private projects (PP) and $70 \%$ for PPP projects [3].

Several members of academia and various political parties in India have condemned the proposed removal of the consent clause. Since forced acquisition is a component of the amendment bill, the market-value approach is inefficient for the land owners. Every owner has their own land valuation, which is subjective. In microeconomic terms, this implies that the utility derived from owning the land is more than just a function of its price. ${ }^{4}$ It could be a function of locational amenities or emotional attachment. If the owner is forced to sell, they may receive disutility from the transaction. If the seller and the buyer negotiate a price, then the buyer could face an exaggerated valuation from the seller. Ghatak and Ghosh propose two solutions for the problem: (1) the transfer price is determined by an auction; and (2) the sellers get an option of compensation in cash or compensation in land [4]. Both proposals make the process fairer for the owners. However, their analysis does not consider the welfare of non-farm members of the society and that the auction price might be too high and not result in an acquisition.

1 The Right to Fair Compensation and Transparency in Land Acquisition, Rehabilitation and Resettlement Act, No. 30 of 2013, Ministry of Law and Justice. Source: http:/ / indiacode.nic.in/acts-in-pdf/302013.pdf.

The values have been in converted from the Indian Rupee to 2015 US dollars.

Applicable for acquisitions over 100 acres in rural areas and 50 acres in urban areas.

Utility is defined as a collection of goods, which satisfy an individual's wants. 
Numerous studies examine the impact of land acquisition on social welfare [5-9]. The majority of the discussion in these studies draws attention to the potential losses for the land owners and not to the benefits that might arise from private or government entities acquiring land for industrial use. "Benefit" is defined as the difference between the potential output or psuedo-output a piece of land would generate if acquired, and the cost to the land owners. For example, suppose the government acquires land for industrial use, if the expected value of the output exceeds the value currently being generated from the unsold land, then the acquisition is warranted. Under the "Consent" clause, this might not occur as the owner has the right to refuse any transaction price. Land acquisition for an infrastructure project is another example. The acquired stretch of land might be used for building a bridge. While the bridge inherently does not produce any output, it facilitates output or pseudo-output production through the commuters who would use the bridge.

Other studies examine the impact of land reform on farmers' welfare and agricultural productivity $[10,11]$. Besley and Burgess deduce that various land reforms in India led to a decrease in poverty [12]. However, they do not investigate whether land used for non-agricultural purposes would have yielded a higher social output. The few studies which examine land conversion from agricultural to non-agricultural use argue that conversion leads to food security and environmental problems favoring the involvement of the government in land use decisions, as the author contends that market-based land allocations might lead to agricultural decline $[13,14]$.

In this paper, we aim to prove that the removal of the "Consent" clause is optimal. We use Pareto efficiency and the Kaldor-Hicks criterion to conduct our analysis. Clearly, forcing owners to surrender their land can skew the wealth distribution of an economy. Therefore, we derive a compensation strategy, which would improve the original act (if implemented), such that it is universally acceptable.

\section{Literature Review of Pareto Efficiency and Kaldor-Hicks Criterion}

In this section, we describe the concept of Pareto Efficiency and its uses in applied microeconomics such as the Kaldor-Hicks criterion. Pareto efficiency or optimality is a state in which no individual can be made better off without making someone else worse-off $[15,16]$. It is usually used in the context of welfare economics, where two or more individuals are endowed with various goods. It addresses the individuals' desire to maximize utility and trade goods with each other at the market price to arrive at an optimal allocation of goods. When the market price is assumed to be exogenous and all individuals are price takers, then the state of optimality is known as a Partial equilibrium [17]. If the market price is endogenous or determined in conjunction with the production process, then the state of optimality is known as a general equilibrium. In our model, we assume that land acquisition will lead to endogenous land prices [18]. Pareto efficiency is attained when no individual can be made better off without compromising someone else's utility.

In real life, attaining Pareto efficiency is difficult. Therefore, most policymakers strive for the second-best outcomes or Pareto-preferred outcomes. This approach is also termed as the Kaldor-Hicks criterion. Under this criterion, as long as societal gains exceed losses from a certain policy's implementation and if the winners can hypothetically compensate the losers-even if such a compensation does not occur), then that policy is justified $[19,20]$. This criterion is the foundation of the modern cost-benefit analysis and has been heavily debated amongst academics and lawmakers. Posner defines the Kaldor-Hicks criterion as wealth maximization and not utility maximization and argues that it is the best tool that policymakers possess to judge the merits of policies or public projects, which involve transactions between willing and unwilling parties [21]. He shows that out of all the decision rules that a government can employ, others being Pareto efficiency and utility maximization, the Kaldor-Criterion is the most pragmatic approach for economic development. Finally, he notes that unlike Pareto efficiency, where the public project may most likely never get undertaken, and utility maximization, where benefits and costs are strictly dependent on the functional form of the researcher, the Kaldor-Hicks criterion forces the government to confront the cost-benefit of a particular policy or project. Therefore, as an example for our case, even if the land policy is not implemented since the 
costs were shown to be higher than the benefits, through the Kaldor-Hicks approach, the government would be better prepared for similar situations in the future, because the value of costs and benefits was computed for the decision.

The total land endowment of a country is fixed and unlike money, it cannot be increased or decreased to attain Pareto efficient outcomes. Therefore, the initial allocation of each individual is already Pareto efficient. Since the redistribution of land is a zero-sum game, where some individuals will win and others will lose, policymakers could invoke the Kaldor-Hicks criterion to justify redistribution. Achieving such allocations is, however, difficult due to political barriers faced by the government. In the case where the government acquires land, the owners could potentially be unsatisfied with the compensation amount. As a consequence, this could lead to an enormous waste of tax-payer resources.

Blume, Rubinfeld, and Shaprio (BRS) argue that tax-payer sponsored compensation for land takings by the government is inefficient, since landowners under the perception that their land will be taken overdevelop their properties such that the value of the land is no longer at the social optimum [22]. Overdevelopment here implies a state where the landowner deliberately reduces the public-use value of the land. BRS further propose that a lump sum payment should only be made if the landowners have made optimal investments in the land. This approach only works if the courts can rely on community standards to determine if the land has experienced overinvestment. Innes further adds that land takings should be avoided unless the public use value is substantially above the private use value to the landowner [23]. However, his analysis does not elaborate on the precise meaning of "substantial". Knetsch and Borcherding, and Cooter propose that the government may create an option with the land owners, which allows them to take the land at any time at a pre-arranged price [24,25]. Since price is pre-negotiated, land owners will not be undercompensated. However, a major drawback of this approach is that reaching a price agreement may prove to be difficult if the owner receives utility from the land, which is more than a function of the price. Miceli builds on BRS's analysis to derive a socially optimum compensation strategy, as long as the taken land's public-use value exceeds the private value to the current owner [26].

While we have discussed the effectiveness of the Kaldor-Hicks criterion and various compensation strategies, the actual compensation amount given to landowners has often been a source of controversy. For example, Keliang et al. observed that out of 476 expropriation cases in China, a majority of the farmers were undercompensated [27]. According to the World Bank's Land and Governance Assessment Framework (LGAF), affected populations in Afghanistan, Brazil, Ethiopia, Nigeria, South Africa, South Sudan, and Tanzania were inadequately compensated for taken land [28]. Van Eerd and Banerjee found similar cases in Cambodia, Indonesia, Sri Lanka, and the Philippines [29]. Cernea notes that a lack of adequate compensation for displaced populations might immediately lead to impoverishment, thereby potentially creating a scenario where the social benefits are in fact lower than the social costs [30]. For example, in India prior to the LARR, 50-55 million people were displaced due to dam construction. According to Cernea, since 2004, 75\% of the displaced populace in India has been inadequately compensated.

Our literature review portrays the delicate balance between the need for the development of societal and compensation strategies that must be enacted if the land owners are in fact willing to transact. The following sections show why the Kaldor-Hicks criterion must be invoked prior to the compensation stage.

\section{Methodology and Theoretical Model}

In this section, we construct a mathematical model to demonstrate the prevailing weaknesses of the "Consent" clause in the LARR Act of 2013. Suppose there are two individuals, a buyer and a land owner. Let index 1 indicate the buyer and 2 indicate the land owner. They both have a concave utility function $U_{1}$ (buyer) and $U_{2}$ (land-owner). Under the construction of a concave utility function, an increasing amount of a good consumed, in our case land, leads to a higher level of satisfaction, such 
that $U_{i=1,2}^{\prime} \geq 0$. However, too much consumption is characterized by diminishing returns, which is mathematically represented by $U_{i=1,2}^{\prime \prime} \leq 0.5$

Let $L$ be the total acreage that the land owner possesses, where $l_{1}$ is the acreage that the buyer desires and $l_{2}$ is the remaining acreage, which the land owner will retain. Each individual's utility is a function of their post-transaction land ownership. It is implied that acquiring acreage $l_{1}$ leaves the buyer with a certain amount of utility $U_{1}\left(l_{1}\right)$ and the land owner with utility $U_{2}\left(l_{2}\right)$. Other parameters, which might alter the shape of the utility function, are considered later. Let $p$ be the per-acre price of $L$. We assume that, if given a choice, the land owner would prefer to keep all their land such that $U_{2}(L)$ $>U_{2}\left(l_{2}\right) .{ }^{6}$ The spatial restraint is: $l_{1}+l_{2}=L$, indicating that the buyer is only transacting with the current land owner and cannot satisfy their utility requirements by acquiring land from other owners. We also assume that the buyer must obtain their optimal land requirement to maximize their utility function. There are no second-best allocations, which will be agreeable to the buyer. For example, suppose that a private entity requires at least $l_{1}$ to complete its project, an allocation less that $l_{1}$ would cause an indefinite stoppage. This outcome is unacceptable to the buyer and hence he or she must obtain $l_{1}$.

We define $x$ as the post-transaction ownership vector agreeable to the land owner and $x^{\prime}$ as the vector agreeable to the buyer. $x^{\prime}$ also provides a higher value of output such that: $v\left(x^{\prime}\right)>v(x)$. The function $v$ here represents the monetary value of the allocation, such that social welfare at $v\left(x^{\prime}\right)$ (when the buyer acquires her desired allocation) is higher than social welfare at $v(x)$ (when the owner keeps her desired allocation). In real life, we can equate this assumption to the public use value or the opportunity cost of the land. For example, suppose there is a farmer producing $y$ amount of gross domestic product (GDP) on a piece of land. If the land buyer from our current problem uses the same piece of land, then the GDP would be higher. Therefore, $v\left(x^{\prime}\right)>v(x)$ indicates that the allocation $x^{\prime}$ can provide a more efficient social outcome. The two vectors represent two conflicting states: $x$ as state 1 and $x^{\prime}$ as state 2 , where land is divided either as $x \mapsto\left(l_{1}, l_{2}\right)$ or as $x^{\prime} \mapsto\left(l_{1}^{\prime}, l_{2}^{\prime}\right)$. In state 1 , the buyer is only able to acquire $l_{1}$ and the land owner keeps $l_{2}$. This transaction is suboptimal for the buyer. In state 2 , the buyer obtains their desired land $l_{1}^{\prime}$ and the land owner is left with $l_{2}^{\prime}$, a transaction suboptimal for the land owner. Figure 1 depicts the two states:

State 1

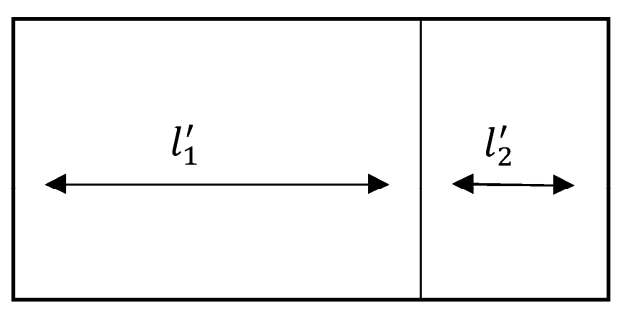

State 2

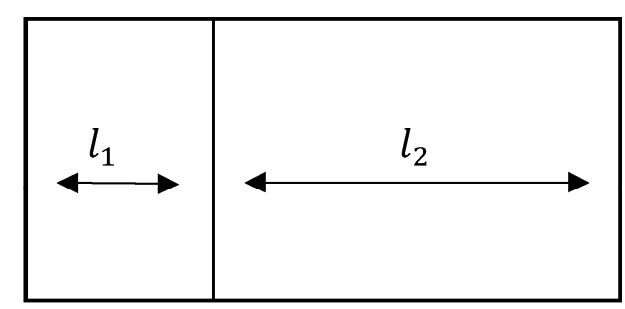

Figure 1. The above figure demonstrates two contrasting situations that may emerge under the current rules of the LARR (2013). In state 1 , the land buyer is able to acquire their desired acreage, which is optimal for them, but not for the owner. In state 2, the land owner is able to retain their desired allocation $l_{2}$, which is optimal for them, but not for the buyer. The total acreage is $L$, which is the same in both states.

5 For more on the mathematical properties of utility functions, see Varian (1993). $U^{\prime}$ is the first differentia with respect to a good consumed by the individual, in this case land. We can also write $U^{\prime}$ as $\frac{\partial U_{i}(.)}{\partial l_{i}}, \forall i=1,2$. Similarly, $U^{\prime \prime}$ is the double derivative or $\frac{\partial^{2} U(\cdot)}{\partial l_{i}^{2}} \forall i=1,2$.

$6 \quad U_{2}(L)>U_{2}\left(l_{2}\right)$ : the utility for the owner from keeping the entire land $L$ is higher than when s/he is left with $l_{2}$ In a real-world context, there might be several cases, where an owner's entire land is bought. But we consider the partial transaction case to create a contrast between the buyer and owner's utility functions. The qualitative results of the model will not change, as will be demonstrated in the analysis. 
Given the assumptions of the post-transaction vectors, it follows that:

$$
\begin{aligned}
& U_{1}\left(l_{1}^{\prime}\right)>U_{1}\left(l_{1}\right) \\
& U_{2}\left(l_{2}\right)>U_{2}\left(l_{2}^{\prime}\right)
\end{aligned}
$$

implying that the buyer obtains a higher utility if state 1 is realized, where the land allocation is $x^{\prime}$ and vice-versa for the land owner. It is easy to presume that: $x^{\prime}>x$, which indicates that $x^{\prime}$ is Pareto preferred to $x$ based on the Kaldor-Hicks compensation criteria. However, we demonstrate that this might not necessarily be the case.

\section{Propositions}

Proposition 1. Given $p$ as the per-acre price of $L$, allocation $x^{\prime}$ can never be realized with the "Consent" clause.

The objective of the buyer is to acquire $l_{1}^{\prime}$ and they are willing to pay $p$ per-acre. We can observe that Equation (2) will never be satisfied if $l_{2}$ is the landowner's final allocation. This is due to the fact that the land owner achieves a higher utility by keeping allocation $l_{2}$. The owner's utility function is only associated with the land that they own and not by its value. The rationale behind the "Consent" clause in LARR Act of 2013 can be explained by removing this assumption. Recall that under the common assumption of Kaldor-Hicks criterion, if the winners, in this case the buyer, as s/he is obtaining her desired allocation $l_{1}^{\prime}$, can compensate the losers (land-owners), then $x^{\prime}$ is Pareto preferred to $x$. We postulate this because the land owners' wealth in state 1 and state 2 remains the same. More formally,

$$
\begin{gathered}
p\left(l_{1}+l_{2}\right)=p L=p\left(l_{1}^{\prime}+l_{2}^{\prime}\right) \\
\Rightarrow p x^{\prime}=p x
\end{gathered}
$$

From Equation (3), it is clear that the transaction transfers wealth and does not create it. ${ }^{7}$ Under the rationale of the consent clause mandated in the LARR Act of 2013, it must be that:

$$
U_{2}\left(V^{\prime}+p l_{1}^{\prime}\right)=U_{2}\left(V+p l_{1}\right)
$$

where $V^{\prime}=p l_{2}^{\prime}$ and $V=p l_{2}$ are the values of the remaining pieces of land under both the states. Equation (5) demonstrates that the utility of wealth in both states is the same, so the owner would be willing to accept the terms of the transaction. However, Equation (5) does not necessarily imply that:

$$
U_{2}\left(V^{\prime}+p l_{1}^{\prime}\right)=U_{2}\left(V+p l_{1}\right) \equiv U_{2}(L)
$$

In Equation (6), the utility of wealth is not similar to the utility of land. This contradiction might arise in a real-life situation. To show this, we return to our private entity example, where the entity makes an offer of $p$ per-acre to the land owner. The land owner might be unwilling to sell due to logistical constraints. Say the owner is a farmer and has a successful operation. While s/he gets the market value for her/his land, s/he might not be able to procure a different piece of land to continue her/his farming operation. Due to this difficulty, s/he might not sell her/his land, despite knowing that her/his net wealth would remain the same. There might be counter examples, where an owner's utility of wealth is equal to their utility of land and therefore a compensation of $p$ per-acre is acceptable to them. But such a solution would not work from the government's viewpoint as it would create an uncertainty in the transaction. The wording of the "Consent" clause leaves acceptance up to the owner, which might result in the inefficient social allocation $x$.

7 The purpose of the transaction from the buyer's viewpoint is to create wealth, but that is a post transaction issue and not relevant to the current discussion. 
Proposition 2. There is no price $p^{\prime}>p$ under the "Consent" clause such that:

$$
U_{2}\left(V+p^{\prime} l_{1}^{\prime}\right)=U_{2}\left(V+p^{\prime} l_{1}\right) \geq U_{2}(L) .
$$

We now consider the case where the buyer offers a price $p^{\prime}$, which satisfies or overcomes the utility of the land restraint in Equation (5). This proposition considers the case of offering a higher compensation price to make $x^{\prime}$ Pareto preferred to $x$. It is conceivable that several owners who were reluctant to sell earlier are now swayed towards acceptance. Yet due to the presence of the "Consent" clause, there will remain a few or several owners who will not accept the trade, since $U_{2}\left(V^{\prime}+p^{\prime} l_{1}^{\prime}\right)=U_{2}\left(V+p^{\prime} l_{1}\right) \neq U_{2}(L)$. Therefore, price $p^{\prime}$ remains an inefficient price from the government's viewpoint, as some owners will always reject any transaction.

Proposition 3. The removal of the "Consent" clause is a necessary yet insufficient condition for social welfare maximization.

Following the conclusion of proposition 1 and 2, we observe the difficulties that the "Consent" clause poses for attaining the preferred allocation $x^{\prime}$. Both propositions convey that there is no compensation price, which satisfies every land owner in the society. If the power is left in the hands of the land owners, then a transaction guaranteeing a more efficient allocation of a land parcel can be vetoed.

We now assume that the "Consent" clause is removed as was desired by the amendment Bill of 2015 and allocation $x^{\prime}$ is achieved with the buyer paying $p$ per-acre to acquire $l_{1}^{\prime}$. Since $v\left(x^{\prime}\right)>v(x)$, social welfare is higher. However, forcing the land owners to concede is only a necessary and not sufficient condition for social welfare maximization. This follows from the fact that the land owners no longer possess their first-choice allocation. Hence, social welfare is higher at $x^{\prime}$ than at $x$, but $x^{\prime}$ is not Pareto or Kaldor-Hicks efficient and social welfare is not maximized. Recall that this is employing the Kaldor-Hicks criterion, since social welfare is higher at $v\left(x^{\prime}\right)$.

Proposition 4. Is there an amount $\mathbf{q}$, with which the government compensates the land owners such that social welfare is maximized at the Pareto preferred allocation $x^{\prime}$, thus satisfying Kaldor-Hicks efficiency?

The buyer has no incentive to pay above the market price $p$ to procure the land, since the lack of a consent clause ensures that the land is sold through eminent domain. It is the only price that maximizes the buyer's profit function. ${ }^{8}$ However, the choice of $p$ may negatively impact the income distribution and consequently prevent social welfare maximization. Therefore, it is the government's responsibility to determine a compensation amount $\boldsymbol{q}=\left(q_{1}, \ldots, q_{n}\right)$, which maximizes the collective utilities of all the individuals in the society. ${ }^{9}$ Let $W\left(U_{1}, \ldots, U_{n}\right)$ be a linear social welfare function, such that:

$$
\underset{q}{\operatorname{Max}} W\left(U_{1}, \ldots, U_{n}\right)=\sum_{i=1}^{n} \alpha_{i} U_{i}\left(\boldsymbol{x}^{\star}, \boldsymbol{q}\right)
$$

subject to,

$$
\boldsymbol{q}\left(\boldsymbol{x}^{\star}\right) \leq B
$$

$W$ is a utilitarian function, with the sum of weighted individual utility functions, and $\alpha_{i}$ represents the welfare weights that are assumed to be the inverse of the marginal utility of incomes (MUI). ${ }^{10}$ By construction, this implies that $\sum_{i} \alpha_{i}=1 . x^{\star}=\left(x_{1}, \ldots, x_{n}\right)$ is the post-transaction allocation vector

8 As mentioned in the LARR Act of 2013, the market price of land is determined by the three provisions mentioned earlier.

$91,2, \ldots, n$ : are the ' $n$ ' members in the society.

10 Mathematically, this implies that, $\alpha_{i}=\frac{\partial U^{\star}\left(x^{\star}, q^{\star}\right)}{\partial I_{i}}$, where $I_{i}$ is an individual's income. 
of all the individuals; $q$ is the compensation amount that the government must decide to give to the affected individuals; and $B$ is the total budget available to the government for the compensations.

Equation (8) requires the government to maximize the social wealth function of the society, by choosing $q$. Solving (8) leads to an optimal compensation amount, which is a function of $\alpha, x^{\star}$, and $B$. More formally,

$$
\boldsymbol{q}=\boldsymbol{q}\left(\alpha, x^{\star}, B\right)
$$

Recall that $x^{\star}$ is a parameter here, since the individual land allocations have already been decided. $\alpha$ is the parameter of interest in this problem and its presence in Equation (10) implies that the compensation amount must depend on the income distribution of the owners whose land is acquired. An individual's marginal utility of income varies with their position on the wealth distribution. We expect a high-income individual (suppose an industrialist) to have a lower marginal utility of income, since a gain of an additional unit of income leads to minimal utility gains. Whereas, a low-income farmer values that additional unit much more than an industrialist. Therefore, if the government forcefully acquires land from an individual who lies on the bottom-half of the income distribution, he or she deserves more compensation than someone who resides in the upper-half. The compensation distribution should mirror the income distribution so that Equation (8) is maximized. In the current wording of the LARR Act of 2013, the market value of land is multiplied by a factor of up to 2 if the land is acquired in rural areas. Special provisions have also been made for lower-caste individuals. However, the Act does not explicitly incorporate compensation based on the income distribution.

In the above analysis, $B$ is assumed to be exogenous, signifying that the government is not concerned about where the funds for compensation come from. In reality, we know that the compensation will be funded by tax-payers of India and therefore B is endogenous. If $B$ is assumed to be endogenous, then the optimal compensation $\boldsymbol{q}^{\star}$ will differ, so we call it $\boldsymbol{q}^{\star \star}$. This is due to the altered budget constraint. The income distribution will be influenced by taxation, which subsequently has an impact on the marginal utilities of income. While qualitatively there is no difference between $\boldsymbol{q}^{\star}$ and $\boldsymbol{q}^{\star \star}$, the quantitative values of both will be different. The precise structural specification of both $\boldsymbol{q}^{\star}$ and $\boldsymbol{q}^{\star \star}$ is beyond the scope of this article.

While this proposition offers a sound compensation strategy, we require quantitative measures of $\boldsymbol{q}$ to convince policymakers. Finding empirical values of $\boldsymbol{q}$ is difficult without the policy being enacted. Therefore, we would have to rely on a simulation exercise, where we estimate MUI weights from the income distribution. For this exercise, we require precise income and land value data, at least at the district level, in order to determine representative MUI weight measures, which is beyond the scope of the current study.

\section{Simulation Exercise for Proposition 4}

In this section, we present a two-person simulation approach for obtaining the MUI weights: $\alpha_{i}$ mentioned in proposition 4. Suppose the functional form of $U_{i}$ is linear-additive in Equation (8), such that $U_{i}()=.q_{i}$. Let $i=1,2$ and the total compensation budget be $\$ 500$. Equation (8) can then be written as:

$$
\underset{q}{\operatorname{Max}} W\left(U_{1}, \ldots, U_{n}\right)=\sum_{i=1}^{2} \alpha_{i} U_{i}\left(x^{\star}, \boldsymbol{q}\right)=\alpha_{1} q_{1}+\alpha_{2} q_{2}
$$

such that (from Equation (9))

$$
\begin{gathered}
q_{1}+q_{2} \leq 500 \\
\alpha_{1}+a_{2}=1
\end{gathered}
$$

Now assume that the maximum possible value for $\alpha_{1} q_{1}+\alpha_{2} q_{2}$ is bounded at some finite utility level $\bar{U}$ and the maximum possible budget is $\$ 500$. Further suppose that prior data indicates that 
person 1 has a marginally higher household income than person 2, implying that the compensation vector will satisfy: $q_{1} \leq q_{2}$. For this simulation, we assume that:

$$
\frac{8}{9} I_{2}=I_{1}
$$

where $I_{i=1,2}$ are the household incomes of persons 1 and 2, respectively. Equation (14) shows that person 1 's income is assumed to be $\left(\frac{8}{9}\right)^{\text {th }}$ of person 2's income. Therefore, the objective function is specified in Equation (11) and the constraints are in (12)-(14). Recall that according to the Kaldor-Hicks criterion: $\max W() \geq$.$B must hold for efficiency. Next, we run the above model in the statistical software \mathrm{R}$ (see code in the Appendix A). The results from the simulation are presented in the Table 1 below.

Table 1. Simulation results.

\begin{tabular}{ccc}
\hline $\mathbf{f f}_{\mathbf{1}}$ & $\mathbf{f f}_{\mathbf{2}}$ & Maximized Objective Function $\boldsymbol{W}^{\star}$ \\
\hline 0.1 & 0.9 & 261.76 \\
0.2 & 0.8 & 258.82 \\
0.3 & 0.7 & 255.88 \\
0.4 & 0.6 & 252.94 \\
0.5 & 0.5 & 250.00 \\
0.6 & 0.4 & 247.05 \\
0.7 & 0.3 & 244.11 \\
0.8 & 0.2 & 241.17 \\
0.9 & 0.1 & 238.23 \\
\hline
\end{tabular}

We can clearly see that the objective function in Equation (11) is maximized when $\boldsymbol{\alpha}_{\mathbf{1}}=\mathbf{0 . 1}$ and $\alpha_{2}=0.9$. ${ }^{11}$ The optimal values of the compensation vector are $q_{1}^{\star}=\$ 235.29$ and $q_{2}^{\star}=\$ 264.70$, which satisfy are assumed constraint: $\boldsymbol{q}_{\mathbf{1}} \leq \boldsymbol{q}_{\mathbf{2}}$ and allocate the entire budget for compensation. These values are in line with the theoretical specification of our model illustrated in proposition 4 . Note that social welfare is maximized when the MUI weight is most skewed in favor of the low-income household.

\section{Conclusions}

India is a developing economy and due to stable population growth, large scale industrialization is required to keep the GDP growth rate positive. The LARR Act of 2013 is a huge step in the correct direction and the amendment bill, as shown through the propositions, might have enhanced the effectiveness of the Act. It would have ensured faster development of the manufacturing sector and Special Economic Zones (SEZs), which might lead to a higher job and GDP growth rate. While concerns relating to the small scale agricultural producers and poor land owners in general are valid, the potential benefits of the removal of the consent clause cannot be discounted. The government of India, after its failure to pass the proposed amendment bill, introduced the Model Leasing Act (2016), which intends to skirt the problem of forced land acquisition. This Act would allow the government to lease land for development at the market rental rate for a fixed duration. The land owners will retain full ownership under this Act. While this solution may seem favorable, the long-term costs to the tax-payers have not been examined.

The Kaldor-Hicks criterion is a potent decision tool available to any national government. Unlike Pareto efficiency, where optimal outcomes for each member of the society are a pre-requisite for any policy to be implemented, the Kaldor-Hicks criterion allows the government to make a decision by comparing the policy's benefits to its costs. This approach permits faster developmental possibilities and forces the government to consider the current and long-term benefits and costs of a

11 We do not include any other combination of $\alpha_{1}$ and $\alpha_{2}$ since no other combination satisfies $\alpha_{1}+\alpha_{2}=1$. 
policy. However, we do not deny the shortcomings of the criterion. Since the criterion relies heavily on wealth and utility maximization, the distributional effects of a policy are ignored in favor of total benefits. It is possible that the benefits and costs are interpreted differently under wealth maximization and utility maximization. For example: if a private land buyer succeeds in obtaining her desired allocation and only produces value for herself, which exceeds the total costs to the government and/or landowners, then the Kaldor-Hicks efficiency would have been achieved, since wealth was maximized. However, under utility maximization, a single land buyer gaining land for private use would never exceed the collective utilities of several landowners, irrespective of the value generated and thus not Kaldor-Hicks efficient. This is why we chose utility maximization to develop our propositions, since total utility from potential land acquisition should exceed the sum of landowners' lost utility and the compensation disbursed by the government.

In this article, we derive conditions based on the Kaldor-Hicks criterion to show that removing the "Consent" clause is necessary for social welfare maximization. The presence of the "Consent" clause can lead to failed transactions and productivity losses for the economy. Some owners will always agree to the transaction and the compensation terms in the original Act of 2013, which as we observed, could potentially induce inefficient compensation from the government, yet some owners will always decline any transaction irrespective of the compensation on offer. Given this scenario, the removal of the "Consent" clause coupled with a compensation based on the marginal utility of income is an effective policy solution. Compensation based on income distribution might be politically difficult to implement, since the biggest conflicts may arise between mid-income and poor farmers or landowners. Mid-income farmers may feel that they are being treated unfairly, despite it being optimal from the government's viewpoint. In view of such disagreements, the government's decision to offer higher compensation to rural land owners is unsurprising. However, we maintain that compensation based on marginal utility of income is the correct approach as it maximizes social welfare, as seen from the simulation exercise, and helps maintain a balanced budget.

Author Contributions: Sankalp Sharma wrote the original draft, developed the methodology and conducted the formal analysis. He also conducted the simulation exercise and wrote the program codes. Anil Giri provided valuable feedback on the first draft and helped edit the methodological section. Tajamul Haque contributed in a supervisory role and was a co-conceiver of the original question. Iuliia Tetteh reviewed the original draft and helped edit the current version of the draft.

Conflicts of Interest: The authors declare no conflict of interest.

\section{Appendix A. R-Programming Code for Simulation to Determine MUI Weights}

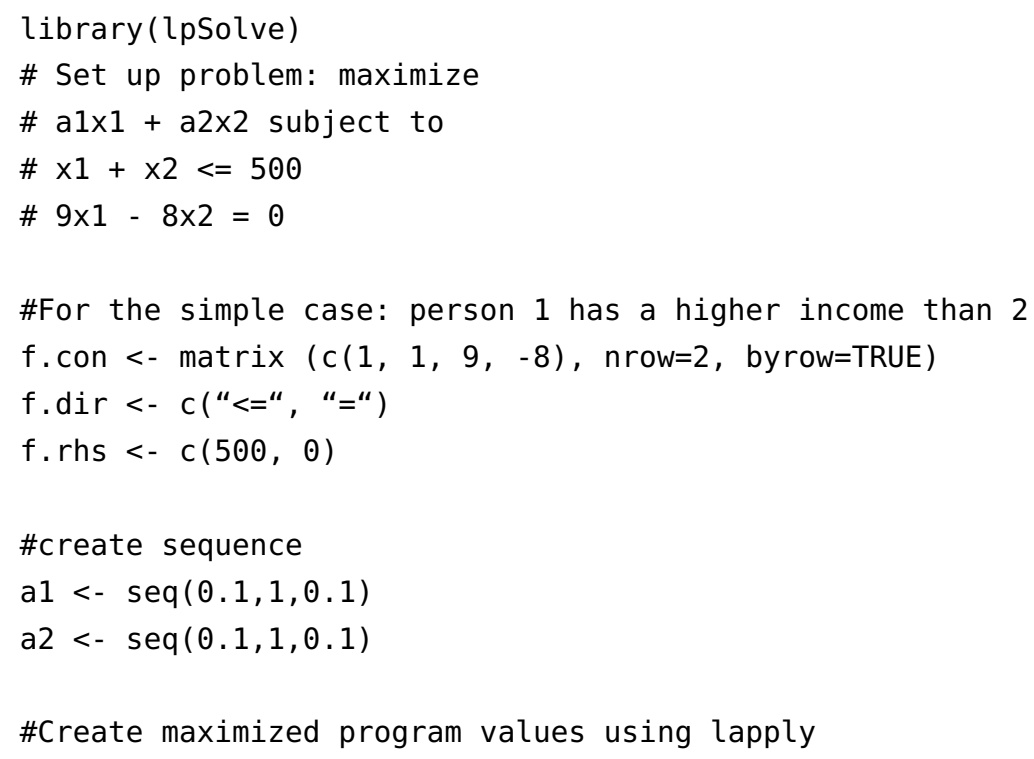




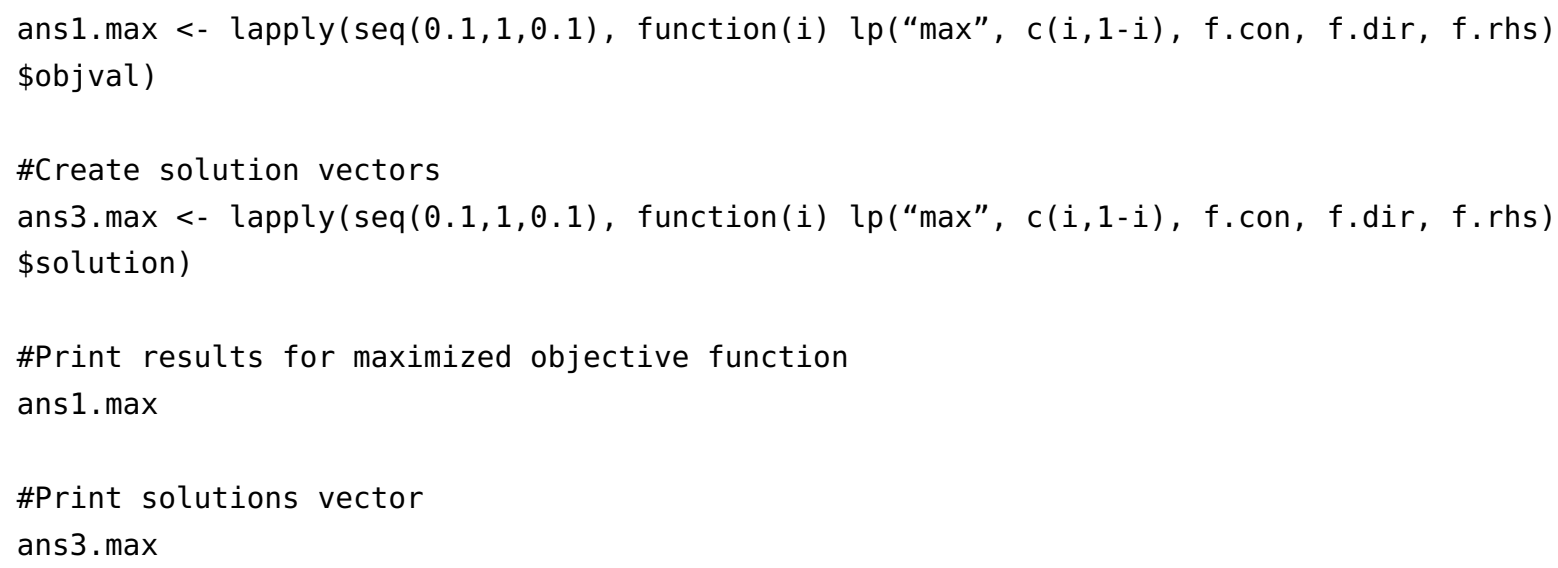

\section{References}

1. Corkindale, J. The Land Use Planning System; Institute of Economic Affairs: London, UK, 2004; ISBN 0-255-36550-0.

2. The Right to Fair Compensation and Transparency in Land Acquisition, Rehabilitation and Resettlementt Bill, Act of 2013. Available online: http:/ /indiacode.nic.in/acts-in-pdf/302013.pdf (accessed on 15 November 2015).

3. The Right to Fair Compensation and Transparency in Land Acquisition, Rehabilitation and Resettlement (Second Amendment) Bill, 2015. Available online: http://www.prsindia.org/uploads/media/Land\% 20and\%20R\%20and\%20R/LARR\%20(2nd\%20A)\%20Bill,\%202015.pdf (accessed on 15 November 2015).

4. Ghatak, M.; Ghosh, P. The Land Acquisition Bill: A Critique and a Proposal. Econ. Political Wkly. 2011, 46, 65-72.

5. Fernandes, W.; Das, J.C.; Rao, S. Displacement and rehabilitation: An estimate of extent and prospects. Dev. Displac. Rehabil. 1989, S, 62-68.

6. Fernandes, W.; Thukral, E.G. Development, Displacement, and Rehabilitation: Issues for a National Debate; Indian Social Institute: Delhi, India, 1989.

7. Cernea, M.M.; McDowell, C. (Eds.) Risk and Reconstruction: Experiences of Resettlers and Refugees; World Bank Publications: Washington, DC, USA, 2000.

8. Pellissery, S.; Biswas, S.D. Emerging Property Regimes in India: What it Holds for the Future of Socio-Economic Rights? Working Paper 234; Institute of Rural Management Anand: Gujarat, India, 2012.

9. Terminski, B. Development-induced displacement and resettlement: Theoretical frameworks and current challenges. Development 2013, 10, 101. Available online: http://hdl.handle.net/10535/8833 (accessed on 11 November 2015).

10. Ghatak, M. Land Reform in India. In The Oxford Companion to Economics in India; Oxford University Press: Oxford, UK, 2007; Available online: http:/ / eprints.lse.ac.uk/id/eprint/5877 (accessed on 15 November 2015).

11. Deininger, K.; Songqing, J.; Nagarajan, N.K. Efficiency and equity impacts of rural land rental restrictions: Evidence from India. Eur. Econ. Rev. 2008, 52, 892-918. [CrossRef]

12. Besley, T.; Burgess, R. Land Reform, Poverty Reduction, and Growth: Evidence from India. Q. J. Econ. 2000, 115, 389-430. [CrossRef]

13. Quasem, M.A. Conversion of agricultural land to non-agricultural uses in Bangladesh: Extent and determinants. Bangladesh Dev. Stud. 2011, 34, 59-85.

14. Wu, J. Land use changes: Economic, social, and environmental impacts. Choices 2008, 23, 6-10.

15. Pareto, V. Manuel D'économie Politique, 2nd ed.; Girand: Paris, France, 1927.

16. Varian, H. Microeconomic Analysis, 3th ed.; Viva Books: New York, NY, USA, 1992; p. 506.

17. Kreps, D.M. A Course in Microeconomic Theory; Princeton University Press: Princeton, NJ, USA, $1990 ;$ p. 41.

18. Wen, H.; Allen, C.G. Relationship between urban land price and housing price: Evidence from 21 provincial capitals in China. Habitat Int. 2013, 40, 9-17. [CrossRef]

19. Kaldor, N. Welfare Propositions of Economics and Interpersonal Comparisons of Utility. Econ. J. 1939, 49, 549-552. [CrossRef]

20. Hicks, J.R. The Foundations of Welfare Economics. Econ. J. 1939, 49, 696-712. [CrossRef] 
21. Posner, R.A. Cost-benefit analysis: Definition, justification, and comment on conference papers. J. Legal Stud. 2000, 29, 1153-1177. [CrossRef]

22. Lawrence, B.; Rubinfeld, D.L.; Shapiro, P. The Taking of Land: When Should Compensation Be Paid? Q. J. Econ. 1984, 99, 71-92.

23. Innes, R. The Economics of Takings and Compensation When Land and Its Public Use Value Are in Private Hands. Land Econ. 2000, 76, 195-212. [CrossRef]

24. Knetsch, J.; Borcherding, T. Expropriation of Private Property and the Basis for Compensation. Univ. Tor. Law J. 1979, 29, 237-252. [CrossRef]

25. Cooter, R. Unity in tort, contract, and property: The model of precaution. Calif. Law Rev. 1985, 73, 1-51. [CrossRef]

26. Miceli, J.T. Compensation for the Taking of Land under Eminent Domain. J. Instit. Theor. Econ. (Zeitschrift Für Die Gesamte Staatswissenschaft) 1991, 147, 354-363.

27. Keliang, Z.; Prosterman, R.; Jianping, Y.; Ping, L.; Riedinger, J.; Yiwen, O. The Rural Land Question in China: Analysis and Recommendations Based on a Seventeen-Province Survey. Int. Law Politics 2006, 38, 761-839.

28. Tagliarino, N.K. The Status of National Legal Frameworks for Valuing Compensation for Expropriated Land: An Analysis of Whether National Laws in 50 Countries/Regions across Asia, Africa, and Latin America Comply with International Standards on Compensation Valuation. Land 2017, 6, 37. [CrossRef]

29. Van Eerd, M.; Banerjee, B. Working Paper I: Evictions, Acquisition, Expropriation and Compensation: Practices and Selected Case Studies; United Nations Human Settlements Programme: Nairobi, Kenya, 2013.

30. Cernea, M. Impoverishment Risks, Risk Management, and Reconstruction: A Model of Population Displacement and Resettlement. In Proceedings of the UN Symposium on Hydropower and Sustainable Development, Beijing, China, 27-29 October 2004.

(C) 2018 by the authors. Licensee MDPI, Basel, Switzerland. This article is an open access article distributed under the terms and conditions of the Creative Commons Attribution (CC BY) license (http:/ / creativecommons.org/licenses/by/4.0/). 